\title{
Dynamic Land Use Change Prediction and Analysis of Its Impacts on Streamflow for Dabus Watershed, Upper Blue Nile Basin
}

\author{
Neseredin Mangel ${ }^{1 *}$; Fitsum Berhe $(\mathrm{PhD})^{2^{*}}$
}

\begin{abstract}
1* Civil Engineering Department (Hydraulic Engineering), Addis Ababa Science \& Technology University, Addis Ababa, Ethiopia, 16417, E-mail: nerehwre2017@gmail.com

$2^{2 *}$ Assistant professor of Civil Engineering (Hydraulics), Head Center of Excellence in Construction Quality \& Technology Civil Engineering Department, Addis Ababa Science, and Technology University, Addis Ababa, Ethiopia, 16417, E-mail: fitsum.tesfaye@ aastu.edu.et
\end{abstract}

\begin{abstract}
Based on the recorded watershed characteristics, the future conditions on the basin system can be predicted using a different method. In this study, dynamic land-use change and its impacts on the streamflow for the Dabus watershed were predicted using ANN-CA based method. The model performance for accurate prediction of the future land-use change on the Dabus River watershed has been checked by validation of the simulated value with the actual value, hence the overall kappa value $(\mathrm{k})=0.83$ for the simulated 2016-LULC validated with actual 2016-LULC. Then, 2026-LULC was predicted based on the 2004 and 2009-LULC. The streamflow for the case of 2004 and 2009-LULC has been simulated using the SWAT model. The value of NSE $=0.87$ and 0.90 was attained during validation of simulated streamflow for 2004 and 2009-LULC data cases, respectively. The agreement of simulated value of streamflow with the observed data is indicated as $R^{2}=0.91$ and 0.96 for 2004LULC and 2009-LULC. The effects of the dynamic land-use change on streamflow for the predicted land use(2026-LULC) catchment were evaluated by T-test analysis. Hence, T-stat $=0.04$ and -0.002 in the case of simulated streamflow used 2004LULC and 2009-LULC, respectively compared with simulated value using 2026-LULC.
\end{abstract}

Key Ward: streamflow, dynamic land-use change, ANN, SWAT, Dabus river

\section{Introduction}

Land-use change is always caused by multiple interacting factors (Lambin et al. 2003). The changes in land-use/land cover is the major factors influencing the hydrologic process, including the streamflow (Guo et al. 2008), surface runoff generation(Shi et al. 2007), ground-water recharge (Mishra and Kumar 2015), evapotranspiration(Dias et al. 2015; Wang et al. 2014), lateral flow, water yield (Gumindoga et al. 2014; Gashaw et al. 2018). The sets of the deriving forces of the land-use changes vary in time and space. Based on the specific human activities in a particular environment. The main sets of the deriving factors for the land-use changes include natural variability, economic and technological factors, demographic factors, institutional factors, and cultural factors. In another word, the dynamic land-use change can occur due to the increasing agricultural land use or expansion of built-up areas including urban areas. The increase in agricultural land use results in an increase in evapotranspiration, water yield, and sediment yield in the watershed system. Whereas, the expansion of urban areas led to a decrease in evapotranspiration, water yield, and sediment yield (Aghsaei et al. 2020).

In Ethiopia, high population relying only on natural resources improper land management (Garzanti et al. 2006; Kidane and Alemu 2015). Rapid population growth in the upper Blue Nile basin has led to fast land-use changes from natural forest to agricultural land. This resulted in speeding up the soil erosion process in the highlands and increasing sedimentation further downstream in reservoirs and irrigation canals (Ali et al. 2015). The annual predicted sediment load from the Blue Nile basin for land use at 1973 and 2000 years was show increases by 53\% at the outlet of the basin within
28 years past ago (Gebremicael et al. 2013). The seasonal and annual trend analysis was shown the streamflow significantly increases within a wet season and short season and significant decreases within the dry season. As a result, the increases in the annual streamflow and sediment load at the outlet of the basin was dynamic land-use change.

Several hydrology models can be used to assess the impacts of land use/land cover change on the hydrologic responses of a catchment, for the land use/land cover data derived from the remote sensing. These including Hydrologic Simulation Program Fortran (HSPF) model (Zhang and Ross 2015), MIKE SHE (Im et al. 2009), PRMS (Legesse et al. 2010), HBV (Ashagrie et al. 2006), HEC-HMS (Younis and Ahmad 2018), DHSVM(Safeeq and Fares 2012), WaSIMETH (Bormann and Elfert 2010), SWAT(Bieger et al. 2015). However, the SWAT model has been mostly applied to assess the impacts of land-use change on catchment hydrology, around the world.

The aim of this study is to predict the land-use change and to analyze their impacts on the streamflow in the Dabus River watershed.

\section{Description of Study Area}

The Dabus River is a north-flowing tributary of the blue-Nile River in southwestern Ethiopia. It bound within 34 $28^{\prime} 53.57^{\prime \prime}$ West longitude, $10^{\circ} 45^{\prime} 09.69^{\prime \prime}$ North latitude, 35³8'21.64" East longitude, $8^{\circ} 52^{\prime} 16.34^{\prime \prime}$ south latitude and it joins its parent stream at $10^{\circ} 36^{\prime} 38^{\prime \prime} \mathrm{N} 35^{\circ} 8^{\prime} 58^{\prime \prime} \mathrm{E}$, sees Figure 1. Its watershed covers an area of about 14725.39 square kilometers. The altitude in the Dabus sub-basin ranges approximately between 485 and 3150 above mean sea level. The sub-basin has an annual rainfall ranging between $970 \mathrm{~mm}$ 
and $1985 \mathrm{~mm}$. The annual maximum and minimum temperature in the sub-basin vary between $20^{\circ} \mathrm{c}-35^{\circ} \mathrm{c}$ and $8.5^{\circ} \mathrm{c}-20^{0} \mathrm{c}$ respectively.

\section{Input Data}

The actual LULC classification of the Dabus watershed for 2004, 2009, and 2016 was processed from the satellite image data, see Figure 2. The thematic images are acquired from ESA Glob cover land cover of $0.3 \mathrm{~km}$ resolution for the period December 2004 and December 2009. The Sentinel-2A thematic image of $20.5 \mathrm{~m}$ resolution was acquired from ESA-
CCI-land cover for the period December 2016. The soil data for the watershed was acquired from FAO classification of the world soil map ( $1 \mathrm{~km}$ resolution). The daily meteorological includes rainfall $(\mathrm{mm})$, temperature $\left(\mathrm{T}^{\circ} c\right)$, wind speed $(\mathrm{m} / \mathrm{s})$, relative humidity $(\%)$, solar radiation $\left(\mathrm{kwh} / \mathrm{m}^{2}\right)$ from January to December 2000-2016 were obtained from Ethiopia national meteorology agency. The measured streamflow at the Dabus gauging station was obtained from Ethiopia Ministry of Water Resource for the calibration and validation of the model.

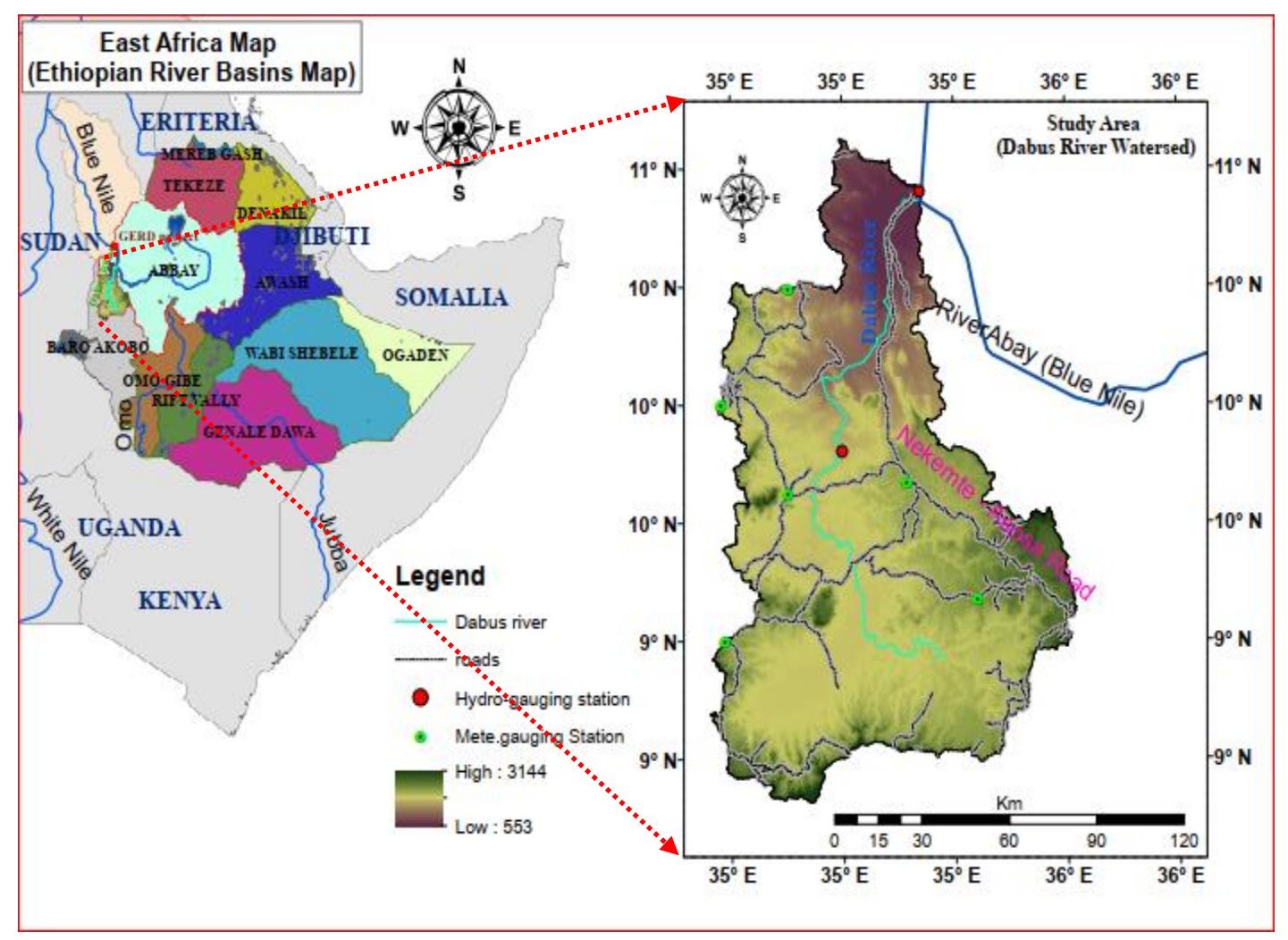

Figure 1Location of Study Area

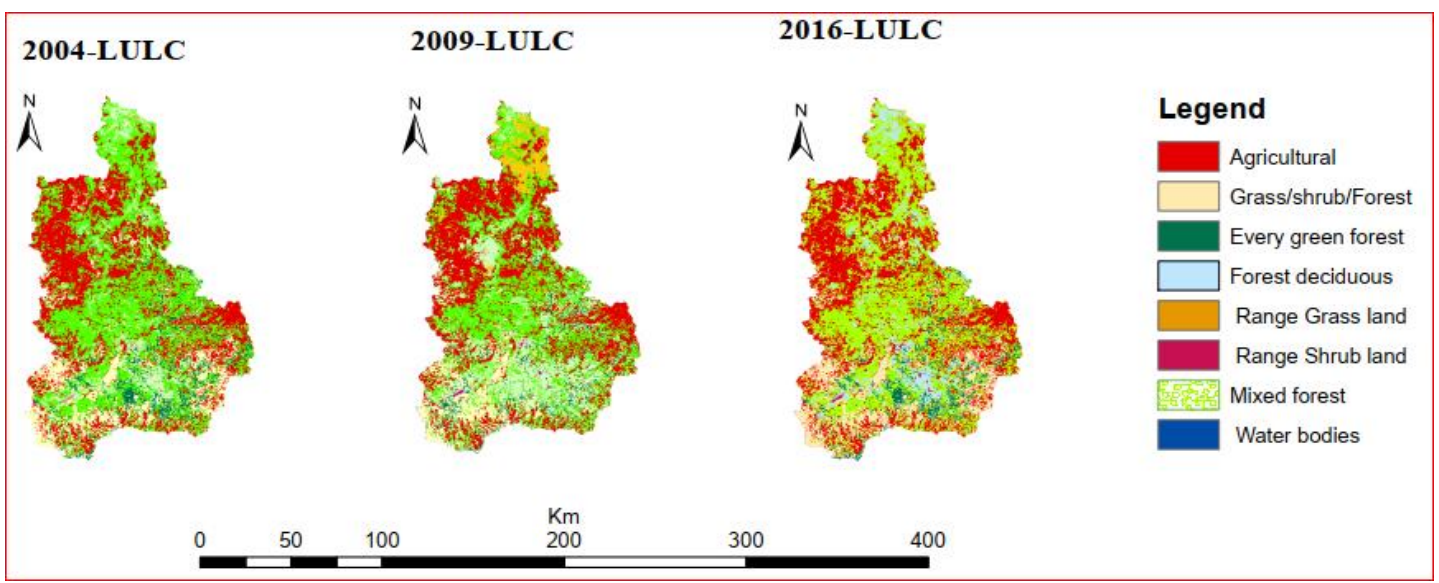

Figure 2 Land use/land cover Satellite image 


\section{Model Description}

\subsection{ANN Model}

In QGIS, the raster analysis window allows the analysis of land-use change detection and prediction of the possible value required output layers based on the behavior of the input layer through MOLUSCE. In this method, the Pearson correlation transition matrix algorithm is given in Eq. (1) is applied to calculate the area of change map of land use classes in the system. In MOLUSCE four different methods available to perform the transition potential model, thus includes ANN(MLP), WoE, MCE, LR. The MLP and LR method behavior are similar, in which the initial state raster and raster factor are taken as input data to generate the target output. The weight of evidence (WoE) method is used to process the binary map. The change map divided into series of binary maps (one map per transition class), then the set of weight are estimated for every binary map. Whereas in the Multi-Criteria Evaluation method, the factor raster is the input data and places, where the transition occurs, are target values. It takes a pairwise comparison matrix of factors and calculates the weights of every factor. Furthermore, Artificial Neural Network(ANN) was developed to model the brain interconnected system of neurons so that the computer could perform as the brain ability to arrange the patterns and train from the trial and error, thus observing the relations from input data (Pijanowski et al. 2002). It has been used in variety of discipline for pattern recognition such as landscape classification (Brown et al. 1998; Huang et al. 2009), sediment transport evaluation (Ebtehaj and Bonakdari 2014), suspended sediment load prediction (Rajaee et al. 2011), climate forecasting (Roetter et al. 2005), reservoir inflow prediction (Jain et al. 2000).

$$
\begin{aligned}
& P_{i j}=P\left(X_{t+1}=j \mid X_{t}=i\right) \quad \text { Eq. (1) } \\
& \text {, for } i, j \in \text { state space, } \mathrm{t}=0,1,2 \ldots . \mathrm{N} \\
& \text { Or }
\end{aligned}
$$

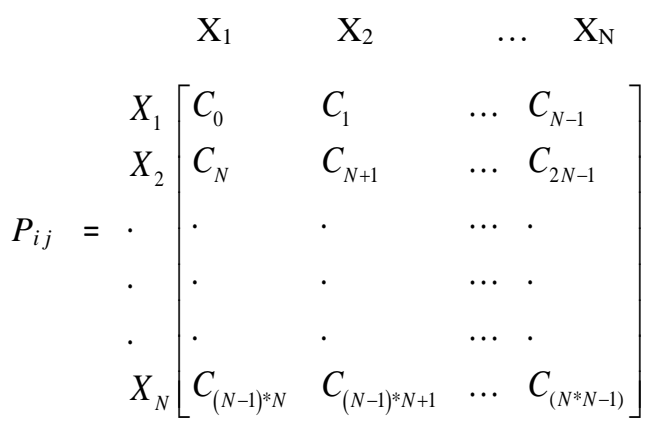

Where: - $\mathrm{C}_{0}$ is the count of unchanged pixels of land use or land cover in class- $1, \mathrm{C}_{1} \ldots \ldots \mathrm{C}_{\mathrm{N} * \mathrm{~N}-1}$ is the count of the transit pixels to the corresponding land use or land cover class, $\mathrm{X}_{1}$, $\mathrm{X}_{2} . . . \mathrm{X}_{\mathrm{N}}$ represents the land use or land cover class code, $\mathrm{P}_{i j}$ is transition probabilities.

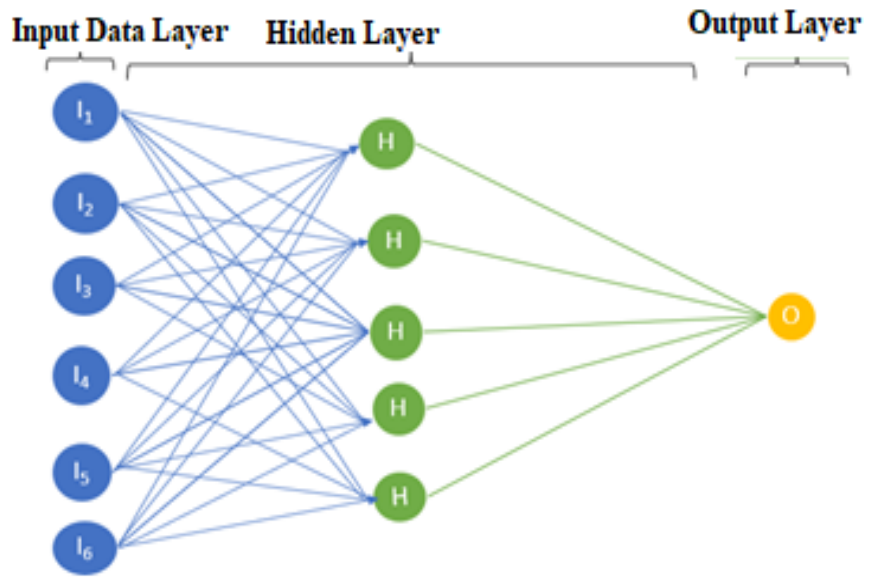

Figure 3 Artificial-Neural Network (ANN) -based Cellular Automata (CA) model structure

In this study, the ANN method is selected to perform the transition potential model as pre-stage for prediction of landuse change at the period 2026 using Cellular Automata (CA) simulator based on the initial LULC change behavior in the Dabus watershed in 2004 \& 2009. The structure of MPL consists of three-layer such as input layer, hidden layer, and output layer, see Figure 3.

\subsection{SWAT Model}

The SWAT (Soil and Water Assessment Tool) model is a continuous-time, process-based river basin model. It was developed to evaluate the effects of alternative management decisions on water resources and nonpoint-source pollution in large river basins (Arnold et al. 2012). The SWAT model describes the large-scale spatial variability of soil, land cover, and managements by discretizing the catchment into many sub-divisions. The discretization is carried out in two stages, the first stage is sub-dividing the large complex topographic basin area into sub-basins based on the defined threshold area. In the second stage, the sub-basins are further subdivided into one or more homogenous hydrologic response units (HRUs). The model computes the output of water, sediment, nutrient, and pesticide based on individual HRUs developed from the land use, soil, and slope parameters in the catchment.

In the SWAT model, different routing techniques are uses with the associate to the stream reaches and basins outlets in the channel network. The water flow in the streams can be routed either by variable storage routing or Muskingum routing method. The variable storage routing method used in SWAT was proposed by Williams (1969) is based on the continuity equations given as Eq. (2)

$$
\begin{gathered}
V_{\text {in }}-V_{\text {out }}=\Delta V_{\text {stored }} \quad \text { Eq. (2) } \\
\text { Or } \\
\left(\frac{q_{\text {in }, 1}+q_{\text {in }, 2}}{2}\right) \Delta t-\left(\frac{q_{\text {out }, 1}+q_{\text {out }, 2}}{2}\right) \Delta t=\Delta V_{\text {stored }}
\end{gathered}
$$




$$
T t=\frac{V_{\text {stored }}}{q_{\text {out }}} \quad \text { Eq. (3) }
$$

Where $V_{\text {in }}$ and $V_{\text {out }}=$ volume of water entered $\left(\mathrm{m}^{3}\right)$ and left the reach respectively, $T T=$ travel time in second, $q_{i n}$ and $q_{\text {out }}=$ rate of flow $\left(\mathrm{m}^{3} / \mathrm{s}\right)$ with water entered and left the reach with a given time step $\Delta t$.

The Muskingum routing method used in SWAT is based on the Muskingum Cung (1969) method that uses the match diffusivity concept. The rout equation is given as Eq. (4).

$$
Q_{2}=C_{1} I_{2}+C_{2} I_{1}+C_{3} Q_{1} \quad E q \text {. (4) }
$$

Where

$$
C_{1}=\frac{-2 k \theta+\Delta t}{2 k(1-\theta)+\Delta t}, C_{2}=\frac{2 k \theta+\Delta t}{2 k(1-\theta)+\Delta t}, C_{3}=\frac{2 k(1-\theta)-\Delta t}{2 k(1-\theta)+\Delta t}
$$

Where $\mathrm{k}=$ storage time constant for the reach (s), $\theta=$ weighting factor (0-0.5), $I_{2}=$ inflow at the end of time step $(\mathrm{m} 3 / \mathrm{s}), I_{1}=$ inflow at the beginning of time step $(\mathrm{m} 3 / \mathrm{s}), Q_{2}=$ the outflow at the end of time step (m3/s), $Q_{1}=$ the outflow at the beginning of the time step $(\mathrm{m} 3 / \mathrm{s})$.

In the SWAT model, the hydrologic cycle of a sub-basin is simulated based on the water balance equation. It is given as Eq. (5)

$$
S W_{t}=S W_{o}+\sum_{i=1}^{t}\left(R_{d a y}-Q_{\text {suff }}-E_{a}-W_{p e r}-Q_{g w}\right) E q . \text { (5) }
$$

Where $S W_{t}$ is the final water content on day t $(\mathrm{mm}), S W_{o}$ is the initial water content on a day i (mm), $R_{d a y}$ is the amount of rainfall on a day i (mm), $Q_{\text {surf }}$ is the amount of surface runoff on a day $\mathrm{i}(\mathrm{mm}), E_{a}$ is the amount of evapotranspiration on a day $\mathrm{i}(\mathrm{mm}), W_{p e r}$ is the amount of water percolating into the soil or entering the vadose zone from the soil profile on a day $\mathrm{i}(\mathrm{mm})$ and $Q_{g w}$ is the amount of groundwater return flow on a day $\mathrm{i}(\mathrm{mm})$.

\subsection{Model Performance Evaluation}

In MOLUSCE, the validation of the model is carried out by comparing the predicted land use the actual land use. And the kappa statistics Eq. (6) is used to check the model performance. In the case of the streamflow, Nash-Sutcliffe model coefficient (NSE) Eq. (7) and coefficient of determination $\left(\mathrm{R}^{2}\right)$ Eq. (8) are used to check the agreement of the simulated value with the observed value.

$$
\begin{aligned}
& \boldsymbol{k}=\frac{\boldsymbol{p}_{a}-\boldsymbol{p}_{e}}{\mathbf{1}-\boldsymbol{p}_{e}} \\
& N S E=1-\frac{\sum_{i=1}^{n}\left(O_{i}-S_{i}\right)^{2}}{\sum_{i=1}^{n}\left(O_{i}-\bar{O}\right)^{2}}
\end{aligned}
$$

$$
R^{2}=\frac{\left[\sum_{i=1}^{n}\left(O_{i}-\bar{O}\right)\left(S_{i}-\bar{S}\right)\right]^{2}}{\sum_{i=1}^{n}\left(O_{i}-\bar{O}\right)^{2} \sum_{i=1}^{n}\left(S_{i}-\bar{S}\right)^{2}}
$$

Where:

$$
p_{a}=\sum_{i, j=1}^{c} p_{i j}, p_{e}=\sum_{i, j=1}^{c} p_{i T} \square p_{T j}, p_{\max }=\sum_{i=1}^{c} \min \left(p_{i T}, p_{T j}\right)
$$

and $P_{i j}$ is the $\mathrm{i}, \mathrm{j}^{\text {th }}$ cell of a contingency table, $P_{i T}$ is the sum of all cells in the $\mathrm{i}^{\text {th }}$ row, $P_{T_{j}}$ is the sum of all cells in the $\mathrm{j}^{\text {th }}$ column, c is the count of raster classes, $K$ is kappa, $\mathrm{S}_{\mathrm{i}}$ and $\mathrm{O}_{\mathrm{i}}$ are simulated and observed values during model evaluation at time step $\mathrm{i}^{\text {th }}$ respectively, $\overline{\mathrm{O}}$ is the average observed value, and " $n$ " is the number of values.

\section{Result and Discussion}

\subsection{Land Use Change model}

The satellite image of the Dabus watershed in 2004 and 2009 were used to prepare the land use/land cover map in ArcGIS. For the prediction of land use /land cover map at period 2026, the land use/ land cover data for 2004 and 2009 were used as the initial parameters to the analysis in method of land use simulation change (MOLUSCE). In another word the area of land us change from 2004-2009 were used to obtain the proportion of the transition matrix value. The map of ecluiden- distance from the Road map on the Dabus watershed, the slope map, and DEM of the Dabus watershed are taken as the variable parameters for raster correlation evaluation. The results of the area LULC change from 2004 to 2009 are summarised in Table 1, And the cross-tabular transition matrix proportion values in Table 2 The analysis of the Artificial Neural Network (MLP) was done after the map of LULC change created by the transition matrix proportion value given in Table 2. The performance of the model (ANN mothed) for the prediction of the required value (land-use change map at 2026) was trained for 1000 iterations. So, the validation kappa value from the trained model, $\mathbf{k}=\mathbf{0 . 7 4}$, and the agreement in the model for the analysis were represented in Figure 4.

Based on the transition matrix proportion value obtained in table 2, the Cellular Automata Simulator tool simulates the land use data for period 2016 and referenced actual land use map obtained from the satellite image at 2016 of the Dabus watershed was used to validate the model and the performance of this model is measure as the overall kappa $(\mathrm{k}=$ $0.83), \mathrm{k}_{\mathrm{his}}=0.86, \mathrm{k}_{\mathrm{loc}}=0.89$ and $\%$ of correctness $=76.54$. And then for these reasons the 2026-LULC from 2004 \& 2009LULC was predicted using Cellular Automata (CA), see Figure 5. In this study, from the predicted land use map (2026LULC), the area of agricultural land and mixed forest on the Dabus watershed shows increases, whereas the other shows a decrease as compared to 2016-LULC and 2009-LULC. But as compared to the 2004-LULC, the area of agricultural land including ranged grassland and forest deciduous are increased and the others are decreasing, see in Table 3. 
Table 1 LULC area change from 2004-2009 periods

\begin{tabular}{llccc}
\hline \multirow{2}{*}{ No LULC-type } & Area $(\%)$ & Area $(\%)$ & $\Delta \%[2004-$ \\
& & 2004 & 2009 & $2009]$ \\
\hline 1 & Agricultural & 31.48 & 32.03 & 0.55 \\
2 & Grass/shrub/Forest & 12.95 & 11.03 & -1.92 \\
3 & Every green forest & 4.90 & 3.47 & -1.42 \\
4 & Forest deciduous & 8.01 & 15.56 & 7.55 \\
5 & Range Grassland & 0.32 & 4.24 & 3.93 \\
6 & Range Shrub land & 0.26 & 0.24 & -0.02 \\
7 & Mixed forest & 42.07 & 33.42 & -8.65 \\
8 & Water bodies & 0.00 & 0.00 & 0 \\
\hline
\end{tabular}

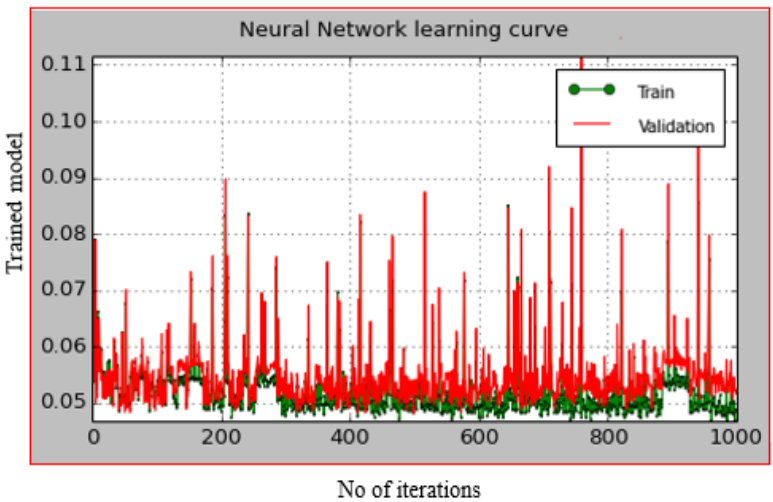

Figure 4 ANN trained model curve

Table 2 Cross-tabular transition matrix for change map analysis algorithm

\begin{tabular}{|c|c|c|c|c|c|c|c|c|c|}
\hline \multirow{2}{*}{\multicolumn{2}{|c|}{$\begin{array}{c}\text { Transition } \\
\text { matrix }\end{array}$}} & \multicolumn{8}{|c|}{ 2009-LULC } \\
\hline & & $\begin{array}{l}\text { Agricultu } \\
\text { ral }\end{array}$ & $\begin{array}{c}\text { Grass/shrub/ } \\
\text { Forest }\end{array}$ & Every green forest & $\begin{array}{c}\text { Forest } \\
\text { deciduous }\end{array}$ & $\begin{array}{c}\text { Range } \\
\text { Grassland }\end{array}$ & $\begin{array}{c}\text { Range } \\
\text { Shrubland }\end{array}$ & $\begin{array}{c}\text { Mixed } \\
\text { forest }\end{array}$ & Water bodies \\
\hline \multirow{8}{*}{ 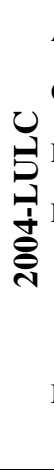 } & Agricultural & 0.8 & 0.022 & 0.009 & 0.0518 & 0.0199 & 0 & 0.094 & 0 \\
\hline & Grass/shrub/Forest & 0.12 & 0.468 & 0.065 & 0.0798 & 0.0015 & 0 & 0.265 & 0 \\
\hline & Every green forest & 0.013 & 0.169 & 0.186 & 0.44 & 0.00013 & 0.000348 & 0.19 & 0 \\
\hline & Forest deciduous & 0.018 & 0.05 & 0.04 & 0.469 & 0.08 & 0.00638 & 0.33 & 0 \\
\hline & Range Grass land & 0.013 & 0.0004 & 0.0069 & 0.035 & 0.81 & 0.0038 & 0.128 & 0 \\
\hline & Range Shrub land & 0.007 & 0.059 & 0.0388 & 0.193 & 0.0084 & 0.68 & 0.019 & 0 \\
\hline & Mixed forest & 0.117 & 0.071 & 0.026 & 165 & 0.064 & 0 & 0.556 & 0 \\
\hline & Water bodies & 0 & 0 & 0 & 0.2 & 0.12 & 0 & 0.2 & 0.48 \\
\hline
\end{tabular}

Table 3 Predicted land use (2026-LULC) and land-use change percentage

\begin{tabular}{llccccc}
\hline No & LULC & $\begin{array}{c}\text { Actual }-2016 \\
\left(\mathrm{~km}^{2}\right)\end{array}$ & $\begin{array}{c}\text { Simulated }-2026 \\
\left(\mathrm{~km}^{2}\right)\end{array}$ & $\begin{array}{c}\Delta \% \\
{[2016-2026]}\end{array}$ & $\begin{array}{c}\Delta \% \\
{[2009-2026]}\end{array}$ & $\begin{array}{c}\Delta \% \\
{[2004-2026]}\end{array}$ \\
\hline 1 & Agricultural & 4959.29 & 5095.60 & 0.93 & 2.67 & 3.22 \\
2 & Grass/shrub/Forest & 1610.41 & 1571.68 & -0.26 & -0.33 & -2.25 \\
3 & Every green forest & 195.45 & 86.90 & -0.74 & -2.88 & -4.31 \\
4 & Forest deciduous & 2281.27 & 2176.18 & -0.72 & -0.74 & 6.81 \\
5 & Range Grass land & 430.17 & 295.40 & -0.92 & -2.23 & 1.69 \\
6 & Range Shrub land & 13.77 & 12.56 & -0.01 & -0.15 & -0.17 \\
7 & Mixed forest & 5195.41 & 5447.45 & 1.72 & 3.67 & -4.98 \\
8 & Water bodies & 0.18 & 0.18 & 0.00 & 0.00 & 0.00 \\
\hline
\end{tabular}




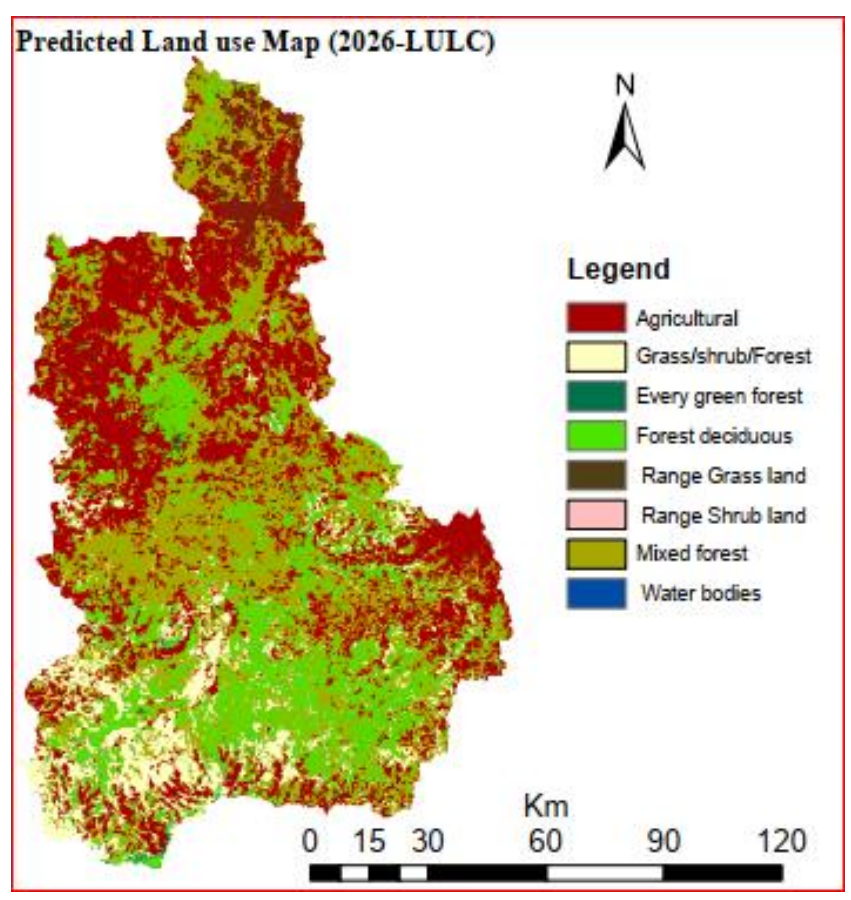

Figure 5 Predicted land use (2026-LULC)

\subsection{Streamflow model}

The streamflow at the Dabus watershed was simulated using 2004-LULC, 2009-LULC, 2026-LULC by assuming the climatic characteristics in 2026 are the same as the 2016 climates' condition. The contributions of the land use to the streamflow (groundwater, surface runoff, percolation of rainfall into the soil) for the simulated land use or land cover (2026-LULC) was compared with the simulated value for 2004-LULC and 2009-LULC. The estimated maximum \% groundwater for $2004 \& 2009$-LULC was observed from the area covered with every green forest. But for 2026-LULC the max.\% GW from the area covered with mixed forest and

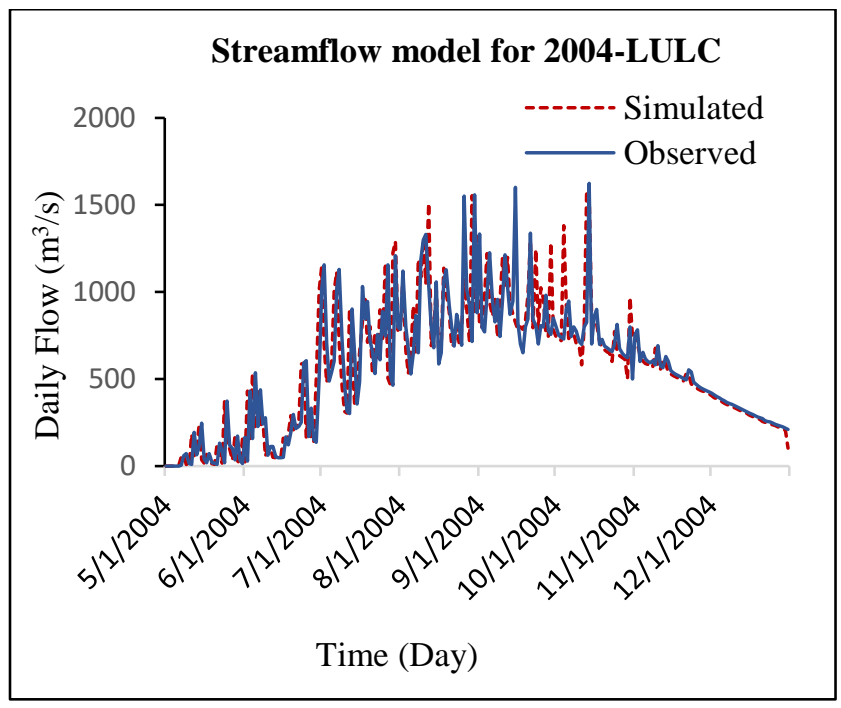

Figure 6 Simulated daily streamflow for 2004-LULC deciduous forest contribute to groundwater. The maximum surface runoff (Q) is calculated from agricultural land and forest deciduous land in each case. Due to the increasing area of agricultural land as shown in the 2004-LULC to 2009LULC and 2009-LULC to 2026-LULC, the estimated surface runoff show increase by $2.58 \%$ from 2004 -LULC to 2009 LULC and $4.84 \%$ from 2009-LULC to the predicted land use (2026-LULC) for cultivated land. For forest deciduous land the surface runoff increases by $4.57 \%$ f from 2004-2009's LULC and $6.06 \%$ for 2009 to 2026-LULC. Whereas the percentage of percolated water into the soil is maximum at the area covered by forest deciduous and every green forest in both 2004-LULC \& 2009-LULC, but for the predicted one the report shows the maximum percolation will occur at the area of catchment covered by agriculture, forest deciduous, mixed forest and ranged grass in Dabus watershed.

In this study, the validated simulated streamflow for 2004LULC data is represented in Figure 6 and its statistical values of the model performances are NSE $=0.87, \mathrm{R}^{2}=0.91$. And validated streamflow model used 2009-LULC data is shown in Figure 7 and its statistical values of the model performance are $\mathrm{NSE}=0.9$ and $\mathrm{R}^{2}=0.96$. The homogeneity of simulated streamflow for the predicted land use (2026-LULC) was tested using T-test by assuming equal variance to the simulated streamflow using 2004-LULC and 2009-LULC. As a result, shows that $\mathrm{T}$-stat values are less than the $\mathrm{t}$-critical value in both cases, the detail is presented in Table 4 \& Table 5. In which the p-values indicate that the results are almost similar at $\alpha=5 \%$ significance level.

Hence in this study, the result shows that there is no any more difference within the simulated streamflow for the dynamic land-use change (2026-LULC) as compared with that of the simulated streamflow for 2004 and 2009-LULC at the Dabus watershed for the same climatic characteristics.

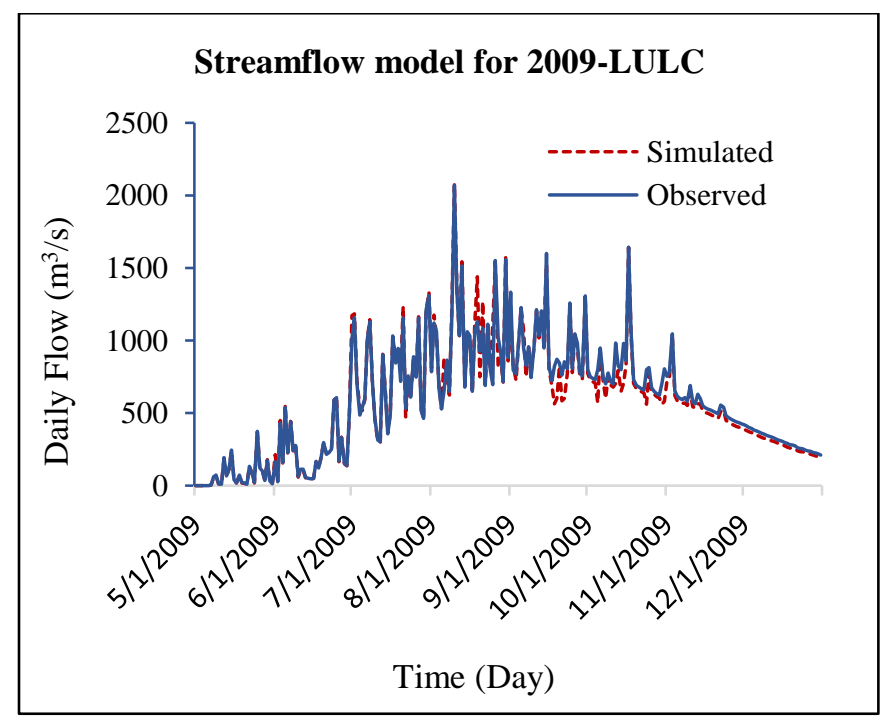

Figure 7 Simulated daily streamflow for 2009-LULC 


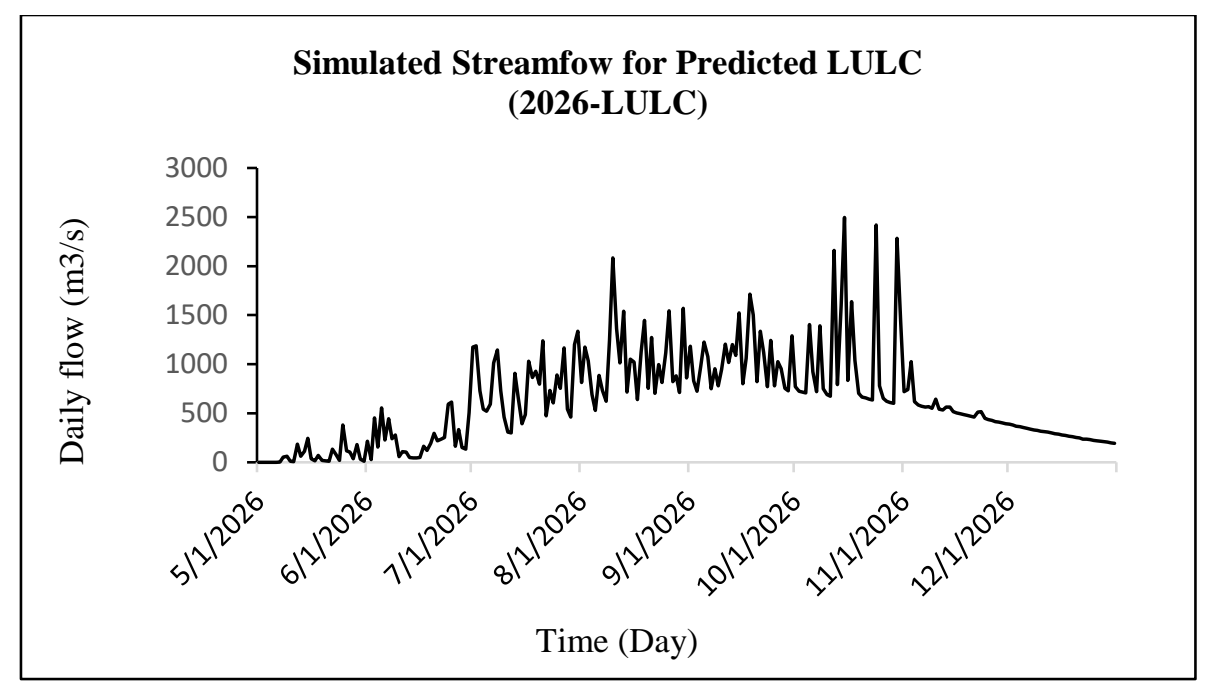

Figure 8 Simulated Daily streamflow for 2026-LULC

Table 4 T-test: for null hypothesis $\left(\sigma_{1}=\sigma_{2}\right)$

\begin{tabular}{lrrr}
\hline Streamflow for LULC & $@ 2004$ & $@ 2026$ & Results \\
Mean & 630.35 & 628.68 & \\
Variance & 220899.72 & 226624.05 & \\
Observations & 245 & 245 & \\
Pooled Variance & 223761.89 & & \\
df & & & 488 \\
T - Stat & & & $\mathbf{0 . 0 4}$ \\
P-Value & & & 0.97 \\
T-Critical & & & 1.96 \\
\hline
\end{tabular}

Table 5 T-test: for null hypothesis $\left(\sigma_{1}=\sigma_{2}\right)$

\begin{tabular}{lrrr}
\hline Streamflow for LULC & $@-2009$ & @-2026 & Results \\
\hline Mean & 628.59 & 628.68 & \\
Variance & 226414.99 & 226624.05 & \\
Observations & 245 & 245 & \\
Pooled Variance & 226519.52 & & \\
df & & & 488 \\
T-Stat & & & $\mathbf{- 0 . 0 0 2}$ \\
P-Value & & & 1.00 \\
T-Critical & & & 1.96 \\
\hline
\end{tabular}

\section{Conclusion}

The dynamic land-use change in 2026 for Dabus catchments was predicted using ANN-CA based analysis method. As the output of the model, the Agricultural land area was shows expansions by $0.93 \%$ than 2016-LULC, $2.67 \%$ than 2009-LULC, 3.22\% than 2004-LULC. And also, the catchment area covered by the mixed forest was shows increases in the predicted land use (2026-LULC) map by $1.72 \%$ than 2016-LULC and $.367 \%$ than 2009-LULC, but it is reduced by $4.98 \%$ as compared with $2004-L U L C$. This means the increasing or decreasing coverage area of one type of land use shows that the conversion of one type of land use to another type in the watershed due to many factors. However, for this rate of change in land use in this watershed, the streamflow will not affect any more if the climatic characteristics are keeping constant.

The model performances acquired in this study are the overall $\mathrm{kappa}(\mathrm{k})=0.83$ when the simulated 2016-LULC by ANN-CA is validated with the actual land use on the Dabus watershed. The Nash-Sutcliffe efficiency (NSE) is 0.87 and 0.9 for the validated streamflow model using 2004-LULC and 2009-LULC in the SWAT model, respectively. The coefficient of the simulated model agreement to the observed value was measured as $\mathrm{R}^{2}=0.91$ and 0.96 for 2004-LULC and 2009-LULC used in the model. The effects of the dynamic land-use change on the streamflow were checked by T-test analysis using the simulated streamflow for the predicted land use map and the streamflow obtained using the actual land use map on the Dabus watershed (2004-LULC \&2009-LULC). However, the results show that streamflow patterns are similar. In Figure 8 the graph shows that the expected pattern of the daily streamflow hydrograph at the outlet of the Dabus watershed.

\section{Acknowledgment}

This study was a part of my original Thesis research, which I have conducted for the award of Master of Science in Hydraulic Engineering at Addis Ababa Science and Technology University (AASTU). I would like to express my gratitude to Assosa University (ASU) that grant me this chance to attained my study in this program. I extend my gratitude to the Ethiopian National meteorology service Agency and the ministry of water resources energy and irrigation for providing the climate and river flow data. And my great appreciation to European Space Agency for providing Glob cover land cover satellite image. 


\section{References}

Aghsaei, Helen, Naghmeh Mobarghaee Dinan, Ali Moridi, Zahra Asadolahi, Majid Delavar, Nicola Fohrer, and Paul Daniel Wagner. 2020. "Effects of Dynamic Land Use/Land Cover Change on Water Resources and Sediment Yield in the Anzali Wetland Catchment, Gilan, Iran." Science of the Total Environment 712: 136449. https://doi.org/10.1016/j.scitotenv.2019.136449.

Ali, Yasir S A, Alessandra Crosato, Yasir A Mohamed, and . 2015. "Sediment Balances in the Blue Nile River Basin." International Journal of Sediment Research 29 (3): 316-28. https://doi.org/10.1016/S10016279(14)60047-0.

Arnold, J. G., D. N. Moriasi, P. W. Gassman, K. C. Abbaspour, M. J. White, R. Srinivasan, C. Santhi, et al. 2012. "SWAT: Model Use, Calibration, and Validation." Transactions of the ASABE 55 (4): 14911508. https://doi.org/10.13031/2013.42259.

Ashagrie, A. G., P. J.M. De Laat, M. J.M. De Wit, M. Tu, and S. Uhlenbrook. 2006. "Detecting the Influence of Land Use Changes on Discharges and Floods in the Meuse River Basin - The Predictive Power of a Ninety-Year Rainfall-Runoff Relation?" Hydrology and Earth System Sciences $10 \quad$ (5): $\quad 691-701$. https://doi.org/10.5194/hess-10-691-2006.

Bieger, Katrin, Georg Hörmann, Nicola Fohrer, and . 2015. "The Impact of Land Use Change in the Xiangxi Catchment (China) on Water Balance and Sediment Transport." Regional Environmental Change 15 (3): 485-98. https://doi.org/10.1007/s10113-013-0429-3.

Bormann, H., and S. Elfert. 2010. "Application of WaSiMETH Model to Northern German Lowland Catchments: Model Performance in Relation to Catchment Characteristics and Sensitivity to Land Use Change." Advances in Geosciences 27: 1-10. https://doi.org/10.5194/adgeo-27-1-2010.

Brown, Daniel G, David P Lusch, Kenneth A Duda, and . 1998. "Supervised Classification of Types of Glaciated Landscapes Using Digital Elevation Data" 21: 233-50.

Dias, Lívia Cristina Pinto, Márcia N. Macedo, Marcos Heil Costa, Michael T. Coe, and Christopher Neill. 2015. "Effects of Land Cover Change on Evapotranspiration and Streamflow of Small Catchments in the Upper Xingu River Basin, Central Brazil." Journal of Hydrology: Regional Studies 4 (PB): 108-22. https://doi.org/10.1016/j.ejrh.2015.05.010.

Ebtehaj, Isa, and Hossein Bonakdari. 2014. "Evaluation of Sediment Transport in Sewer Using Artificial Neural Network" 2060. https://doi.org/10.1080/19942060.2013.11015479.

Garzanti, Eduardo, Sergio Andò, Giovanni Vezzoli, Ada Ali Abdel Megid, and Ahmed El Kammar. 2006. "Petrology of Nile River Sands (Ethiopia and Sudan): Sediment Budgets and Erosion Patterns." Earth and Planetary Science Letters 252 (3-4): 327-41. https://doi.org/10.1016/j.eps1.2006.10.001.

Gashaw, Temesgen, Taffa Tulu, Mekuria Argaw, and Abeyou
W Worqlul. 2018. "Modeling the Hydrological Impacts of Land Use / Land Cover Changes in the Andassa Watershed, Blue Nile Basin, Ethiopia." Science of the Total Environment 619-620: 1394-1408. https://doi.org/10.1016/j.scitotenv.2017.11.191.

Gebremicael, T. G., Y. A. Mohamed, G. D. Betrie, P. van der Zaag, and E. Teferi. 2013. "Trend Analysis of Runoff and Sediment Fluxes in the Upper Blue Nile Basin: A Combined Analysis of Statistical Tests, PhysicallyBased Models and Landuse Maps." Journal of Hydrology 482: 57-68. https://doi.org/10.1016/j.jhydrol.2012.12.023.

Gumindoga, W., T. H.M. Rientjes, A. T. Haile, and T. Dube. 2014. "Predicting Streamflow for Land Cover Changes in the Upper Gilgel Abay River Basin, Ethiopia: A TOPMODEL Based Approach." Physics and Chemistry of the Earth 76-78: 3-15. https://doi.org/10.1016/j.pce.2014.11.012.

Guo, Hua, Qi Hu, Tong Jiang, and . 2008. "Annual and Seasonal Streamflow Responses to Climate and LandCover Changes in the Poyang Lake Basin, China." Journal of Hydrology 355 (1-4): 106-22. https://doi.org/10.1016/j.jhydrol.2008.03.020.

Huang, Jinliang, Zhenshun Tu, Jie Lin, and . 2009. "Land-Use Dynamics and Landscape Pattern Change in a Coastal Gulf Region , Southeast China" 4509. https://doi.org/10.1080/13504500902771891.

Im, Sangjun, Hyeonjun Kim, Chulgyum Kim, and Cheolhee Jang. 2009. "Assessing the Impacts of Land Use Changes on Watershed Hydrology Using MIKE SHE." Environmental Geology $57 \quad$ (1): 231-39. https://doi.org/10.1007/s00254-008-1303-3.

Jain, By S. K., A. Das, D. K. Srivastava, and . 2000. "Application of ANN for Reservoir Inflow Prediction and Operation," no. October: 263-71.

Kidane, Desale, and Binyam Alemu. 2015. "The Effect of Upstream Land Use Practices on Soil Erosion and Sedimentation in the Upper Blue Nile Basin , Ethiopia," no. January.

Lambin, Eric F, Helmut J Geist, Erika Lepers, and .. 2003. "Dynamics of Land-Use and Land Cover Change in Tropical Region." https://doi.org/10.1146/annurev.energy.28.050302.105 459.

Legesse, D, T A Abiye, H Abate, and . 2010. "Streamflow Sensitivity to Climate and Land Cover Changes : Meki River ， Ethiopia," 2277-87. https://doi.org/10.5194/hess-14-2277-2010.

Mishra, Nitin., and S. Kumar. 2015. "Impact of Land Use Change on Groundwater Recharge in Guishui River Basin, China." In HYDRO 2015 INTERNATIONAL 20th International Conference on Hydraulics, Water Resources and River Engineering, 21:734-43. https://doi.org/10.1007/s11769-011-0508-7.

Pijanowski, Bryan C, Daniel G Brown, Bradley A Shellito, and Gaurav A Manik. 2002. "Using Neural Networks and GIS to Forecast Land Use Changes: A Land Transformation Model" 26: 553-75.

Rajaee, Taher, Vahid Nourani, Mohammad Zounemat- 
kermani, and Ozgur Kisi. 2011. "River Suspended Sediment Load Prediction: Application of ANN and Wavelet Conjunction Model," no. August: 613-27. https://doi.org/10.1061/(ASCE)HE.

Roetter, R. P., C. T. Hoanh, A. G. Laborte, H. Van Keulen, M. K. Van Ittersum, C. Dreiser, C. A. Van Diepen, N. De Ridder, and H. H. Van Laar. 2005. "Integration of Systems Network (SysNet) Tools for Regional Land Use Scenario Analysis in Asia." Environmental Modelling and Software 20 (3): 291-307. https://doi.org/10.1016/j.envsoft.2004.01.001.

Safeeq, Mohammad, and Ali Fares. 2012. "Hydrologic Response of a Hawaiian Watershed to Future Climate Change Scenarios." Hydrological Processes 26 (18): 2745-64. https://doi.org/10.1002/hyp.8328.

Shi, Pei Jun, Yi Yuan, Jing Zheng, Jing Ai Wang, Yi Ge, and Guo Yu Qiu. 2007. "The Effect of Land Use/Cover Change on Surface Runoff in Shenzhen Region, China." Catena 69 (1): 31-35. https://doi.org/10.1016/j.catena.2006.04.015.

Wang, Guoqiang, Huicai Yang, Lijing Wang, Zongxue Xu, and Baolin Xue. 2014. "Using the SWAT Model to Assess Impacts of Land Use Changes on Runoff Generation in Headwaters." Hydrological Processes 28 (3): 1032-42. https://doi.org/10.1002/hyp.9645.

Younis, Syed Muhammad Zubair, and Ammar Ahmad. 2018. "Quantification of Impact of Changes in Land UseLand Cover on Hydrology in the Upper Indus Basin, Pakistan." Egyptian Journal of Remote Sensing and Space $\quad$ Science $21 \quad$ (3): $255-63$. https://doi.org/10.1016/j.ejrs.2017.11.001.

Zhang, Jing, and Mark Ross. 2015. "Hydrologic Modeling Impacts of Post-Mining Land Use Changes on Streamflow of Peace River, Florida." Chinese Geographical Science $25 \quad$ (6): 728-38. https://doi.org/10.1007/s11769-015-0745-2. 